\title{
Mycoplasma Hyorhinis in the Etiology of Serositis among Piglets
}

\author{
By N.F. Friis and A.A. Feenstra \\ Natıonal Veterınary Laboratory, Copenhagen, Denmark.
}

\begin{abstract}
Friis, N.F. and A.A. Feenstra: Mycoplasma hyorhinis in the etiology of serositis among piglets. Acta vet. scand. 1994, 35, 93-98. - In a study on the involvement of Mycoplasma hyorhınıs in serositıs of piglets, 26 routine diagnostıc anımals, 3-7 weeks old, with distinct serofıbrinous lesıons in the pericardial, pleural and peritoneal cavities were examined. $M$. hyorhınis was isolated in 9 cases, non-haemolytic Escherichia coll in another 9 cases and in 4 cases both species were found. Neither of the microorganisms were found in the remaining 4 cases.

The presence of $M$ hyorhinis in the serous cavities in the absence of non-haemolytic $E$. coli was always accompanied by a diagnosis of other disease conditions, mainly of the respiratory tract. In the cases infected with non-haemolytic $E$. coll complicating problems were absent.

The pathogenicity of $M$. hyorhinis was further studied by inoculation of 2 young pigs in which the typical serofibrinous lesions of the serous cavities were produced. It therefore appears that $M$ hyorhinis can be regarded as a cause of polyserositis in piglets; under field conditions, however, the synergistic presence of other debilitating syndromes appears necessary for its haematogenous spread from the respiratory tract to the serous cavities.
\end{abstract}

escherichia coli; joints; mycoplasma hyosynoviae; pericardial; pleura; peritoneal; serosa; swine.

\section{Introduction}

Mycoplasma hyorhinis is a very frequently occurring microorganism in swine. Piglets are often infected shortly after birth and the normal habitat is the mucous membranes of the upper respiratory tract and the tonsils. A descending spread to the lungs occurs easily and $M$. hyorhinis is regarded as part of the etiologic complex in pneumonias among piglets (Friis 1971, 1974). Sometimes a haematogenous spread takes place with secondary localizations in the serous cavities of the pericardium, the pleura, the peritoneum and in joints. Pronounced pathologic changes may result and are usually characterized as serofibrinous lesions. They may be found in clinical material (Bannerman \& Nicolet 1971, Carter 1954, Carter \& Schroder 1955, King 1968) and in experimentally inoculated animals as well (Ennis et al. 1971, Friis 1974, Poland et al. 1971, Roberts et al. 1963).

The importance of $M$. hyorhinis as a primary etiological agent in polyserositis and arthritis, alone and in interplay with bacteria, mainly Escherichia coli, still remains unsolved. Therefore, an investigation has been performed with the aim of studying the occurrence of $M$. hyorhinis in serositis piglets sub- 
mitted to this Institute for post mortem examination, and to correlate the findings with the bacteriological results.

\section{Materials and methods \\ Design of the experiment}

Piglets 3-7 weeks old were obtained from the routine diagnostic material sent to the $\mathrm{Na}$ tional Veterinary Laboratory during 4 years, 1989 through 1992.40 piglets with various degrees of inflammatory-like changes of the serous cavities were examined. For control, 8 piglets with other diseases were included. The material originated from 44 herds.

The piglets were examined for Mycoplasma hyorhinis, Mycoplasma hyosynoviae, and bacteria. Mycoplasma hyopneumoniae and Mycoplasma flocculare were disregarded as they need a cultivation time of 3 weeks. Anamnestic information was most often scarce. About $1 / 3$ of the animals had died and another $1 / 3$ was killed before mailing; no history for the remaining pigs was given. Information about antibiotic treatment was usually missing. The age was exactly stated in some cases; otherwise it was estimated at autopsy.

The pathologic changes of the serous cavities were grouped according to intensity of inflammation as distinct, mild or absent. "Distinct" was defined as evident formation of fibrinous material irrespective of the presence of fluid, in at least 1 of the serous cavities. Among the group of distinct changes, comprising 26 cases, 25 showed acute or subacute lesions of serofibrinous/fibrinous nature. The one animal, 5 weeks old, showed lesions dominated by chronic fibrous changes. Among 14 animals of the group "mild", 6 cases were later diagnosed as Mulberry Heart disease. The remaining 8 animals had serofibrinous lesions. The group with normal serous cavities suffered from various diseases of the alimentary tract, joints or skin.

\section{Examination of piglets}

Pathologic changes were noted during the autopsy and swabs were carefully collected from the peritoneal, pleural and pericardial cavities, and from the surface of the brain. Aseptic samples were collected from 3 joints, usually right tarsal, stifle and elbow or visually enlarged joints. Likewise, samples were collected from lung, preferably pneumonic areas, from nasal cavity and tonsil. Tonsil and lung were immersed in boiling water for 5-10 sec and ground, the joints were washed in $96 \%$ ethanol, opened and swabbed.

\section{Isolation and identification of mycoplasmas and bacteria}

The samples were examined for $M$. hyorhinis, $M$. hyosynoviae and bacteria. M. hyorhinis was cultivated in a special medium (Friis et al. 1991) developed for M. hyopneumoniae. In the case of heavily contaminated cultures isolation was reattempted after addition of cycloserine, vancomycin and nalidixic acid to the medium. $M$. hyosynoviae was cultivated in a modified Hayflick-medium enriched with arginine and mucin and made selective against $M$. hyorhinis with cycloserine and Tween 20 (Friis et al. 1991). The primary cultures were kept for 1 week. The disc growth inhibition test was used for identification.

Examination for bacteria was performed by inoculation of the samples onto $5 \%$ calf blood agar (Colombia blood agar base, Oxoid) in 3 different dilutions and onto Drigalski agar (lactose-sucrose-bromthymol blue). Aerobic incubation at $37^{\circ} \mathrm{C}$ was used. The plates were read after 24 and $48 \mathrm{~h}$ incubation. The bacteriological diagnosis was based on standard laboratory identification procedures.

\section{Experimental infection}

Three strains of $M$. hyorhinis isolated from joints or pericardium of 3 piglets were filtered 
Table 1. Isolation of Mycoplasma hyorhınıs and non-haemolytic Escherıchıa coll from 40 routıne autopsy cases of serositis-like changes in piglets together with 8 controls from a total of 44 herds.

\begin{tabular}{lccccc}
\hline Serositıs & $\begin{array}{c}\text { Number of } \\
\text { anımals }\end{array}$ & $\begin{array}{c}\text { M hyorhınıs } \\
\text { without } \\
\text { non-haem E colı }\end{array}$ & $\begin{array}{c}\text { M hyorhınıs } \\
\text { together with } \\
\text { non-haem E colı }\end{array}$ & $\begin{array}{c}\text { Non-haem E colı } \\
\text { without M hyorhınıs }\end{array}$ & $\begin{array}{c}\text { Neither M hyorhınıs } \\
\text { nor non-haem E colı }\end{array}$ \\
\hline distınct & 26 & $9 *(48)$ & $4(4.5)$ & $9(3.6)$ & $4(4.3)$ \\
mild & 14 & $1(6.0)$ & 0 & $4(4.5)$ & $9(3.9)$ \\
absent & 8 & 0 & 0 & $1(5.0)$ & $7(5.3)$ \\
\hline
\end{tabular}

non-haem. = non-haemolytic

* number of piglets; ( ) average age in weeks.

through $0.45 \mu \mathrm{m}$ membrane and cloned once from solid medium. A pool of the 3 strains was inoculated intraperitoneally and intranasally (spray and dropwise) into 2 SPF pigs, 3 months old. $15 \mathrm{ml}$ of a suspension containing $10^{9} \mathrm{ccu}$ of mycoplasma in Hanks' balanced salt solution was inoculated ip into each pig. 1 $\mathrm{ml}$ of culture, approx. $10^{8}$ to $10^{9} \mathrm{ccu}$ was applied dropwise into each nostril of the pigs which were also aerosolated for $5 \mathrm{~min}$. Autopsy with reisolation attempts was done 1 month later.

\section{Results}

Forty piglets with pathological changes in the serous cavities were examined microbiologically. Among the 26 piglets (Table 1 ) with distinct serositis $M$. hyorhınis was found in 9 . Non-haemolytic $E$. coll was found in another 9 cases, while 4 cases contained both microorganisms and 4 contained neither of them.

Of these 4 cases containing neither $M$. hyorhinis nor non-haemolytic $E$. coli together with 9 like animals of group "mild", most were found sterile (not in table) but Haemophilus parasuis, Streptococcus suis and less significant findings were also noted.

In the 13 animals with $M$. hyorhinis present in distinct serositic lesions, these changes were found in all the pericardial and pleural cavities and in 10 of the peritoneal cavities; $M$. hyorhinis was isolated in 11,13 and 8 of the locations, respectively. Titers $\geq 10^{6}$ were often noted. A calculation of the mean age showed that animals with $M$. hyorhinis in serositic lesions were 1 week older than animals with non-haemolytic $E$. coli; however, the difference is uncertain because the age had to be estimated in some cases.

The infections with $M$. hyorhinis and $M$. hyosynoviae at various locations of the animals are described in Table 2. It appears that 8 of the 13 animals infected with $M$. hyorhinis in the serous cavities also showed joint infections. Furthermore, the respiratory tract was found infected with this mycoplasma in 40 of the 48 examined animals. The tonsils were infected in 19 and the brain in 15 cases. M. hyosynoviae was found only in tonsils.

Among the 9 piglets with $M$. hyorhinis infection but without non-haemolytic $E$. coli in the serous cavities, lesions of the respiratory tract, mainly pneumonia were regularly noted. All except 1 were found infected with additional pathogenic bacteria: Actinobacillus pleuropneumoniae (2 cases), Streptococcus suis ( 2 cases), Pasteurella multocida (2 cases), Streptococcus and Pasteurella (1 case), Bordetella bronchiseptica (1 case). These bacteria were found in very low numbers in the serous cavities in 3 animals (2 Streptococcus, 1 Actinobacillus), thus $M$. hyorhinis was present at 
Table 2. Isolation of mycoplasmas from various locations in piglets in relation to the presence/absence of Mycoplasma hyorhinis in serous cavities.

\begin{tabular}{|c|c|c|c|c|c|c|c|c|}
\hline & & & & M. h & yorhınıs & & & M. hyosynoviae \\
\hline & er of anımals & Total & Serosa & Joint & Resp tract & Tonsil & Brain & Tons1l \\
\hline Serositis, distinct & & & & & & & & \\
\hline $\begin{array}{l}\text { M. hyorhinis found in serous cavities } \\
\text { without non-haem. E. coll }\end{array}$ & 9 & 9 & 9 & 5 & 9 & 4 & 5 & 2 \\
\hline $\begin{array}{l}\text { M. hyorhinis found in serous cavities } \\
\text { together with non-haem. E. coli }\end{array}$ & 4 & 4 & 4 & 3 & 4 & 1 & 1 & 1 \\
\hline $\begin{array}{l}\text { M. hyorhinis found in serous cavities, } \\
\text { total }\end{array}$ & 13 & 13 & 13 & 8 & 13 & 5 & 6 & 3 \\
\hline $\begin{array}{l}\text { Non-haem. E. colı found in serous } \\
\text { cavities without M. hyorhınis }\end{array}$ & 9 & 6 & 0 & 0 & 6 & 3 & 4 & 0 \\
\hline $\begin{array}{l}\text { Neither M. hyorhınis nor non-haem. } \\
\text { E. coli found in serous cavities }\end{array}$ & 4 & 4 & 0 & 0 & 4 & 2 & 1 & 1 \\
\hline $\begin{array}{l}\text { M. hyorhınis not found in serous } \\
\text { cavities, total }\end{array}$ & 13 & 10 & 0 & 0 & 10 & 5 & 5 & 1 \\
\hline Serositis, mild & 14 & 11 & 1 & 0 & 10 & 6 & 2 & 1 \\
\hline Serositıs, absent & 8 & 7 & 0 & 0 & 7 & 3 & 2 & 0 \\
\hline
\end{tabular}

non-haem. $=$ non-haemolytic; resp. tract $=$ respiratory tract.

this site in totally pure culture in 6 animals. The 9 piglets represented 9 herds of which most had anamnestic information on different clinical problems, such as pneumonia, diarrhoea, unthriftiness, skin itch, impetigo and influenza. Among the 9 piglets with pure culture of non-haemolytic $E$. coli in the serous cavities, the bacterium could be isolated from almost any site examined, but no other infections or clinical evidence were found.

\section{Experimental infection}

The inoculated pigs showed distinct serofibrinous and fibrinous lesions in the cavities of the pericardium, pleura and peritoneum at autopsy. $M$. hyorhinis was recovered from the pericardial samples of both animals and from the pleural and peritoneal cavities of 1 animal.
The titres varied from $10^{3}$ to $10^{5}$. Concomitant bacteria could not be isolated. The joints showed no obvious enlargement.

\section{Discussion}

In a microbiological study of polyserositis in 3-7 weeks old piglets, 26 cases with distinct serofibrinous lesions of the pericardial, pleural and peritoneal cavities were examined and $50 \%$ (13 animals) were found infected at these sites with $M$. hyorhinis; $15 \%$ (4 animals) of these cases harboured non-haemolytic $E$. coli which was also found in another $35 \%$ (9 animals). Thus, at least 1 of the 2 microorganisms could be isolated from $85 \%$ of the material. From these results it can be concluded that both microorganisms may be involved in the etiology of polyserositis of pig- 
lets. As the 2 organisms appear independently of each other in most cases, they probably represent 2 different disease entities. Among 14 animals with mild changes of the serous cavities only 1 harboured $M$. hyorhinis at these sites.

In the piglets infected in serous cavities with $M$. hyorhinis, lesions of the respiratory tract were usually evident. As various other porcine pathogens were also regularly isolated, it appears likely that the haematogenous spread of $M$. hyorhinis accompanied by development of serositis to some degree depends on the presence of such stressing conditions. On the contrary, the 9 distinct serositic cases caused by non-haemolytic $E$. coli were all without concomitant syndromes or agents. As 13 out of 14 cases of $M$. hyorhinis in serous lesions were evaluated as "distinct", this infection seems apt to result in heavy pathologic changes. The presence of $M$. hyorhinis in fibrinous lesions of the serous cavities is a well known phenomenon, thus Bannerman \& Nicolet (1971) isolated it from 27 (29\%) of 93 cases of pericarditis.

The experimental reproduction of serositis in pigs inoculated with $M$. hyorhinis also suggests that this mycoplasma has a pathogenic capability. A number of other workers has likewise been able to induce serositis. Thus Poland et al. (1971) induced serositis in 4 of 9 gnotobiotic piglets and arthritis was found in 7 of them. In an experiment with 24 piglets inoculated intraperitoneally, Roberts et al. (1963) produced serositis in most animals killed after 6-10 and 15 days. However, pericarditis was found in only 2 of the animals.

It seems reasonable to conclude that $M$. hyorhinis has been etiologically responsible for about one third of the examined 26 clinical cases of distinct serositis in piglets. Reduced resistance resulting from other pathologic conditions appears to be a necessary trigger mechanism for the haematogenous spread accompanied by development of lesions in the serous cavities and joints.

\section{References}

Bannerman ESN, Nicolet J. Isolation and identıfication of porcine Mycoplasma in Switzerland. Schwe1z Arch. Tierheilk. 1971, 113, 697-710.

Carter GR: Observations on pleuropneumonia-like organisms recovered from swine with infectious atrophic rhinitıs and Glasser's disease. Can. J. comp. Med. 1954, 18, 246-251.

Carter GR, Schroder JD: Pleuropneumonia-like organısms associated with pneumonia in swine. Can. J. comp. Med. 1955, 19, 219-220.

Ennis RS, Dalgard D, Willerson JT, Barden JA, Decker JL: Mycoplasma hyorhınıs swine arthritis. II. Morphologic features. Arthr and Rheum. 1971, 14, 202-211.

Frus NF: Mycoplasma hyorhinis as a causative agent in pneumonia of pigs. Acta vet. scand. 1971, 12, 116-119.

Frus $N F \cdot$ Mycoplasmas in pigs with special regard to the respiratory tract. Thesis. DSR Forlag, Copenhagen 1974.

Frus NF, Ahrens $P$, Larsen H: Mycoplasma hyosynoviae isolation from the upper respiratory tract and tonsils of pigs. Acta vet. scand. 1991, 32, 425429.

King SJ: Porcine polyserositis and arthritts - with partıcular reference to mycoplasmosis and Glasser's disease. Austr. vet. J. 1968, 44, 227-230.

Poland J, Edington N, Gols M, Betts AO: The production of pneumonia with or without pleurisy in gnotobiotic piglets with pure cultures of strain TR32 of Mycoplasma hyorhınis. J. Hyg., (Lond.) $1971,69,145-154$

Roberts ED, Swltzer WP, Ramsey FK: Pathology of the visceral organs of swine inoculated with Mycoplasma hyorhinis. Amer. J. vet. Res. 1963, 24, 9-18

\section{Sammendrag}

Den atiologiske betydning af Mycoplasma hyorhinis ved serositts hos smågrise.

Ved en undersøgelse over betydningen af $M$. hyorhl$n i s$ for serositis hos smågrise unders $\varnothing$ gtes $26 \mathrm{dyr}, 3-7$ uger gamle, med tydelige serofibrın $\varnothing$ se betændelsesforandringer 1 de serøse kropshuler. $M$ hyorhinis 
blev påvist 19 tılfælde uden samtıdig forekomst af non-hæmolytıske Escherichia coli. I 4 tilfælde fandtes $M$ hyorhinis sammen med denne bakterie, der tillige blev fundet som monoinfektion hos yderligere 9 dyr. Hos 4 dyr fandtes ingen af de 2 mikroorganısmer.

Tilstedeværelsen af $M$. hyorhinis i de serøse kropshuler uden non-hæmolytıske $E$. coll var altid ledsaget af andre sygdomme, hovedsageligt 1 luftvejene. Ved infektioner med non-hæmolytiske $E$. coll var ledsagesyndromer ikke til stede.
Patogeniteten af $M$. hyorhinis blev yderligere studeret ved podning af 2 unge grise, hos hvilke typiske serofibrinøse læsioner 1 de serøse huler kunne reproduceres.

Det kan derfor konkluderes, at $M$. hyorhınıs må anses for at være ansvarlig for visse tilfælde af serositıs hos smågrise. Imıdlertid synes tilstedeværelse af andre resistensnedsættende sygdomsforhold nødvendig for den hæmatogene spredning af $M$. hyorhinis ledsaget af sekundær lokaliserıng i de serøse huler.

(Recelved July 14, 1993; accepted December 16, 1993).

Reprints may be requested from: N.F. Frus, National Veterınary Laboratory, Bulowsvej 27,

DK-1790 Copenhagen V, Denmark. 